\title{
PENINGKATAN KEMAMPUAN MENGANALISIS BUTIR SOAL TES BAGI GURU-GURU MGMP IPS MENGGUNAKAN PROGRAM QUEST
}

\section{ABILITY IMPROVEMENT OF ANALYZING TEST ITEM FOR MGMP IPS TEACHERS USING QUEST PROGRAM}

\author{
${ }^{1)}$ Hindayati Mustafidah, ${ }^{2)}$ Harjono, ${ }^{3)}$ Agung Purwo Wicaksono \\ 1,2,3 Teknik Informatika, Universitas Muhammadiyah Purwokerto \\ Jl. Raya Dukuhwaluh Purwokerto 53182 \\ email: ${ }^{1}$ fida.mustafidah@gmail.com, ${ }^{2}$ pakjono@gmail.com
}

\begin{abstract}
ABSTRAK
Evaluasi pendidikan adalah kegiatan yang dilakukan dalam rangka mengukur dan menilai segala hal yang termasuk dalam kegiatan pendidikan termasuk di dalamnya hasil belajar.Salah satu instrumen yang dapat digunakan untuk mengukur hasil belajar adalah tes. Namun pada kenyataannya, guru seringkali tidak mengevaluasi soal tes yang disusunnya sehingga tujuan untuk mengukur hasil belajar siswa kurang terpenuhi. Tidak dilakukannya asesmen terhadap kualitas soal tes ini disebabkan oleh waktu dan tenaga yang terbatas, juga kurangnya kemampuan dalam menggunakan alat bantu komputer. Oleh karena itu, dalam kegiatan pengabdian pada masyarakat ini dilaksanakan pendidikan dan pelatihan menggunakan program QUEST untuk membantu melakukan asesmen terhadap kualitas soal tes yang disusunnya. Mitra dalam kegiatan ini adalah guru-guru yang tergabung dalam MGMP IPS SMP Kabupaten Banyumas. Kegiatan ini diikuti oleh 40 orang guru perwakilan dari 25 sekolah. Metode diklat yang digunakan dalam kegiatan ini adalah penyampaian materi dan praktik langsung mengoperasikan program QUEST dan cara membaca hasil keluaran program. Hasil evaluasi dari kegiatan ini menunjukkan bahwa 100\% dari peserta diklat dapat mengoperasikan program QUEST, meskipun hanya 75\% yang mampu membaca hasil keluaran program (menganalisis hasil).
\end{abstract}

Kata Kunci : Asesmen Soal, Instrumen Tes, QUEST, Guru MGMP IPS SMP.

\section{ABSTRACT}

Educational evaluation is an activity undertaken in order to measure and assess everything that is included in the educational activities, thelearning outcomes. One of the instruments that can be used to measure learning outcomes is test. However, in reality, teachers often do not evaluate the test items they have prepared so the objectives of measuring student learning outcomes are not met. The lack of an assessment of the quality of test items is due to limited time and energy, as well as a lack of ability to use computer aids. Therefore, in this community service activity, education and training are conducted using the QUEST program to assist in assessing the quality of test items. Partners in this activity are teachers who are in the group of the MGMP IPS SMP Banyumas District. This activity was attended by 40 representative teachers from 25 schools. The training method used in this activity is the delivery of materials and the directly practice for operating the QUEST program and how to read the output of the program. The results of the evaluation show that 100\% of the training participants can operate the QUEST program, although only $75 \%$ are able to read the program output outcomes (analyze the results).

Keywords : Assessment Of Test Items, Test Instruments, QUEST, Teachers of MGMP IPS SMP 


\section{PENDAHULUAN}

Evaluasi pendidikan adalah kegiatan yang dilakukan dalam rangka mengukur dan menilai segala hal yang termasuk dalam kegiatan pendidikan termasuk di dalamnya hasil belajar.Salah satu instrumen yang dapat digunakan untuk mengukur hasil belajar adalah tes. Secara konseptual, tes itu sendiri menurut Brown (1961) dalam Yusuf (2015) adalah prosedur sistematik untuk mengukur tingkah laku seseorang. Sementara itu, Cronbach (1970) dalam Yusuf (2015) mengemukakan bahwa tes adalah sebuah prosedur sistematis mengobservasi tingkah laku seseorang dan mendeskripsikannya dalam bentuk skala angka atau sistem kategori.Adapun Friedenberg (1995) dalam Yusuf (2015) menyatakan bahwa tes adalah sebuah tipe penilaian yang menggunakan prosedur tertentu untuk memeroleh informasi dan mengonversikan informasi tersebut ke dalam bentuk angka atau skor.Hal ini juga dikemukakan oleh Uno dan Koni (2012) bahwa tes adalah seperangkat rangsangan (stimuli) yang diberikan kepada seseorang (siswa) dengan maksud untuk mendapatkan jawabanjawaban yang menjadi dasar bagi penetapan skor angka.Skor yang didasarkan pada sampel yang representatif dari tingkah laku pengikut tes (siswa) merupakan indikator tentang seberapa jauh siswa tersebut memiliki karakteristik yang sedang diukur.

Sebelum suatu tes hasil belajar suatu mata pelajaran digunakan dalam pengukuran, tes hasil belajar tersebut harus telah dipertimbangkan secara masak. Tes hasil belajar tersebut harus sudah dikenal ciri-cirinya menurut tipenya, telah direncanakan, dan telah disusun berdasarkan petunjuk-petunjuk penyusunannya. Setelah tes hasil belajar tersebut digunakan dalam suatu pengukuran, maka seorang guru akan memperoleh umpan balik tentang mutu tes hasil belajar tersebut.Umpan balik mengenai mutu tes hasil belajar akan diperoleh, apabila seorang guru memeriksa skor-skor yang diperoleh dari suatu pengukuran tersebut.

Dikmenum (2008) menyatakan bahwa kegiatan analisis butir soal bertujuan untuk: (1) menentukan soal-soal yang cacat atau tidak berfungsi penggunaannya; (2) meningkatkan butir soal melalui tiga komponen analisis yaitu tingkat kesukaran, daya pembeda, dan pengecoh soal, serta meningkatkan pembelajaran melalui ambiguitas soal dan keterampilan tertentu yang menyebabkan peserta didik sulit. Di samping itu, butir soal yang telah dianalisis dapat memberikan informasi kepada peserta didik dan guru.Sementara itu Uno dan Koni (2012) menyatakan bahwa tujuan dari analisis butir soal adalah untuk mengadakan identifikasi soal-soal yang baik, kurang baik, jelas, dan yang kurang jelas. Dengan analisis butir soal dapat diperoleh informasi tentang kejelekan sebuah soal dan petunjuk untuk mengadakan perbaikan.

Berdasarkan beberapa informasi yang disampaikan oleh Suwarsito dan Sutomo (2009) dan Mustafidah dan Pinandita (2011), soal tes yang disusun khususnya di Kabupaten Banyumas jarang sekali dilakukan evaluasi atau bahkan tidak dievaluasi sama sekali. Salah satu penyebabnya karena jika menggunakan penghitungan secara manual banyak menggunakan rumussehingga sangat menyita waktu terlebih jika kurang teliti akan memengaruhi hasil perhitungan. Alasan yang paling penting mengapa tidak dilakukannya analisis soal adalah kekhawatiran akan bocornya soal sebelum soal itu benar-benar diujikan kepada siswa. Hal ini disinyalir sebagai salah satu sebab masih belum berkualitasnya soal untuk diujikan ke siswa.Berdasarkan beberapa survei yang dilakukan di sekolah-sekolah di Kabupaten Banyumas, Purbalingga, dan Tegaluntuk tingkat SLTA, SLTP, dan SD, 
Hindayati Mustafidah, Harjono, Agung Purwo Wicaksono

ternyata soal belum memenuhi standar sebagai soal yang berkualitas sebagaimana terlihat pada tabel berikut :

Tabel 1. Hasil Evaluasi terhadap Soal Tes di Beberapa Sekolah di Kabupaten Banyumas, Purbalingga, dan Tegal

\begin{tabular}{|c|c|c|c|}
\hline $\begin{array}{c}\text { Jumlah } \\
\text { Butir }\end{array}$ & $\begin{array}{l}\text { Klasifikasi dalam Taksonomi Revisi } \\
\text { Bloom }\end{array}$ & Validitas Butir Soal & $\begin{array}{c}\text { Reliabilitas Soal } \\
\quad(\alpha=5 \%)\end{array}$ \\
\hline 32 & $\begin{array}{l}\mathrm{C} 1: 21.875 \% \mathrm{C} 2: 9.375 \% \\
\mathrm{C} 3: 59.375 \% \mathrm{C} 4: 9.375 \%\end{array}$ & $\begin{array}{l}\text { SR:58.064\% R : } 32.258 \% \\
\text { S : } 6.452 \% \mathrm{~T}: 3.226 \%\end{array}$ & $\begin{array}{c}0.425 \\
\text { (reliabel) }\end{array}$ \\
\hline 32 & $\begin{array}{l}\mathrm{C} 1: 12.5 \% \mathrm{C} 2: 6.25 \% \\
\mathrm{C} 3: 71.875 \% \mathrm{C} 4: 9.375 \%\end{array}$ & $\begin{array}{l}\text { SR }: 40.625 \% R: 25.000 \% \\
S: 34.375 \%\end{array}$ & $\begin{array}{c}0.549 \\
\text { (reliabel) }\end{array}$ \\
\hline 30 & $\begin{array}{l}\mathrm{C} 1: 13.333 \% \mathrm{C} 2: 6.667 \% \\
\mathrm{C} 3: 70 \% \mathrm{C} 4: 10 \%\end{array}$ & $\begin{array}{l}\text { SR : } 50.000 \% \text { R: } 23.333 \% \\
\text { S: } 26.667 \%\end{array}$ & $\begin{array}{c}0.259 \\
\text { (tidak reliabel) }\end{array}$ \\
\hline 32 & $\begin{array}{l}\mathrm{C} 1: 21.875 \% \mathrm{C} 2: 9.375 \% \\
\mathrm{C} 3: 59.375 \% \mathrm{C} 4: 9.375 \%\end{array}$ & $\begin{array}{l}\text { SR }: 35.484 \% \mathrm{R}: 45.161 \% \\
\mathrm{~S}: 19.355 \%\end{array}$ & $\begin{array}{c}0.464 \\
\text { (reliabel) }\end{array}$ \\
\hline 32 & $\begin{array}{l}\mathrm{C} 1: 12.5 \% \mathrm{C} 2: 6.25 \% \\
\mathrm{C} 3: 71.875 \% \mathrm{C} 4: 9.375 \%\end{array}$ & $\begin{array}{l}\text { SR }: 53.125 \% R: 37.500 \% \\
\text { S : } 9.375 \%\end{array}$ & $\begin{array}{c}0.268 \\
\text { (tidak reliabel) }\end{array}$ \\
\hline 30 & $\begin{array}{l}\mathrm{C} 1: 13.333 \% \mathrm{C} 2: 6.667 \% \\
\mathrm{C} 3: 70 \% \mathrm{C} 4: 10 \%\end{array}$ & $\begin{array}{l}\text { SR : } 53.333 \% \mathrm{R}: 36.667 \% \\
\mathrm{~S}: 10.000 \%\end{array}$ & $\begin{array}{c}0.086 \\
\text { (tidak reliabel) }\end{array}$ \\
\hline 50 & $\begin{array}{l}\mathrm{C} 2: 30 \% \mathrm{C} 3: 58 \% \\
\mathrm{C} 4: 12 \%\end{array}$ & $\begin{array}{l}\text { SR }: 30 \% R: 34 \% \\
S: 30 \% \mathrm{~T}: 6 \%\end{array}$ & $\begin{array}{c}0.818 \\
\text { (reliabel) }\end{array}$ \\
\hline 50 & $\begin{array}{l}\mathrm{C} 2: 30 \% \mathrm{C} 3: 58 \% \\
\mathrm{C} 4: 12 \%\end{array}$ & $\begin{array}{l}\text { SR : } 16 \% \mathrm{R}: 36 \% \\
\mathrm{~S}: 44 \% \mathrm{~T}: 4 \%\end{array}$ & $\begin{array}{c}0.882 \\
\text { (reliabel) }\end{array}$ \\
\hline 20 & $\begin{array}{l}\mathrm{C} 1: 50 \% \mathrm{C} 2: 30 \% \\
\mathrm{C} 3: 10 \% \mathrm{C} 4: 10 \%\end{array}$ & $\begin{array}{l}\text { SR }: 35 \% \mathrm{R}: 40 \% \\
\mathrm{~S}: 20 \% \mathrm{~T}: 5 \%\end{array}$ & $\begin{array}{c}0.370 \\
\text { (tidak reliabel) }\end{array}$ \\
\hline 50 & $\begin{array}{l}\mathrm{C} 1: 40 \% \mathrm{C} 2: 38 \% \\
\mathrm{C} 3: 8 \% \mathrm{C} 4: 14 \%\end{array}$ & $\begin{array}{l}\text { SR }: 58 \% \mathrm{R}: 38 \% \\
\mathrm{~S}: 4 \%\end{array}$ & $\begin{array}{c}0.45 \\
\text { (reliabel) }\end{array}$ \\
\hline 20 & $\begin{array}{l}\mathrm{C} 1: 20 \% \mathrm{C} 2: 35 \% \\
\mathrm{C} 4: 45 \%\end{array}$ & $\begin{array}{l}\text { SR }: 60 \% \mathrm{R}: 20 \% \\
\mathrm{~S}: 15 \% \mathrm{~T}: 5 \%\end{array}$ & $\begin{array}{c}0.520 \\
\text { (reliabel) }\end{array}$ \\
\hline
\end{tabular}

Sumber: Dwiningsih (2006), Hani (2006), Sari (2006), Bennyarsih (2006).

Keterangan:
C1: mengetahui
C2: memahami
C3: mengaplikasikan
C4: menganalisis
C5: mengevaluasi
C6: mencipta
SR: Sangat Rendah
$\mathrm{R}:$ Rendah
S: Sedang
T: Tinggi

Meskipun dari data tersebut diketahui bahwa ternyata soal-soal yang disusun belum semua memenuhi standar kualitas yang diharapkan, namun belum ada usaha yang nyata untuk memperbaikinya. Demikian juga hasil survei lapangan berupa wawancara dengan beberapa tenaga pengajar (guru) di Kabupaten Banyumas mereka jarang sekali bahkan belum pernah melakukan analisis atau evaluasi terhadap soal-soal yang mereka susun untuk mengetahui kualitasnya sebagai alat ukur bagi pembelajaran yang dilakukan. Bahkan hasil kajian yang dilakukan oleh Widodo (2010) disampaikan bahwa pada tahun pelajaran 2008/2009 seluruh guru SD, SMP, SMA BPK PENABUR Tasikmalaya tidak melakukan analisis soaltes formatif. Hanya sebagian kecil guru (SD dua orang, SMP satu orang, dan SMA dua orang) yang melaksanakan analisis butir soal pada 
tes sumatif atau tes evaluasi akhir semester. Padahal analisis soal tes merupakan bagian yang sebenarnya tidak boleh dipisahkan dari tahapan penilaian.Hal ini disebabkan untukmengetahui tingkat keakuratan soal sebagai alat ukur harus dilakukan ujicoba terlebih dahulu sehingga terlalu menyita waktu, tenaga, dan pikiran padahal waktu yang tersedia sangat terbatas sedangkan tugas dan kegiatan yang lain masih banyak yang belum dikerjakan.

Komputer sebagai alat bantu menghitung ternyata masih dirasa sulit bagi sebagian guru untuk melakukan penilaian terhadap kualitas soal yang dibuat. Hal ini disebabkan karena harus mengumpulkan data skor hasil pekerjaan siswa yang diberi tes, kemudian hasil perhitungan dianalisis, yang selanjutnya dilakukan perbaikan-perbaikan terhadap soal yang telah disusun (jika perlu diperbaiki). Hal inilah yang juga dirasa terlalu banyak pekerjaan yang harus dilakukan. Hasil studi yang dilakukan Widodo (2010) menyebutkan bahwa guru enggan melaksanakan penilaian soal tes, karena selain tidak memiliki waktu luang karena jam mengajarnya penuh, juga karena belum atau bahkan tidak mengetahui manfaat dari melakukan asesmen soal tes. Keengganan guru menggunakan komputer sebagai alat bantu untuk melakukan asesmen kualitas soal tes juga disebabkan kurangnya penguasaan guru terhadap pengoperasian komputer.Selain itu, guru merasa tidak ada tuntutan untuk melakukan asesmen.Hal ini tidak sejalan dengan peraturan pemerintah yang tertuang dalam Permendiknas No. 20 Tahun 2007 yang mengatakan bahwa “... dari segi teknik dan instrumen penilaian yang digunakan, setiap satuan pendidikan dituntut memiliki guru yang mampu melakukan pengujian pendidikan dengan instrumen yang benar-benar akuntabel”.

Permasalahan yang dialami oleh guru-guru yang tergabung dalam MGMP IPS SMP Kabupaten Banyumas adalah:

1. Kurang pemahaman mengenai jenis pendekatan analisis butir soal tes.

2. Kesulitan dalam melakukan analisis butir soal tes terutama dengan memanfaatkan program komputer karena guru masih kesulitan dalam mengoperasikannya, apalagi harus menerjemahkan/menafsirkan makna dari keluaran programnya.

3. Membutuhkan pendamping dalam menganalisis butir soal khususnya dalam menggunakan alat bantu program komputer.

Berdasarkan permasalahan yang dialami mitra, maka kegiatan pengabdian pada masyarakat ini bertujuan untuk memberikan pelatihan kepada tenaga pengajar (guru) yang tergabung dalam MGMP IPS SMP Kabupaten Banyumas tentang pemanfaatan teknologi software komputer yaitu "QUEST" untuk membantu dalam menganalisis butir soal yang meliputi validitas, reliabilitas, daya pembeda, dan indeks kesukaran. Selain lebih cepat dibanding dengan penyelesaian dengan cara perhitungan manual, dengan menggunakan peralatan komputer, hasil perhitungan yang didapatkan juga akan lebih teliti.

\section{METODE}

Berdasarkan permasalahan yang
dihadapi dan manfaat yang bisa
diharapkan, maka akan ditawarkan
kegiatan pendidikan dan pelatihan
(workshop) bagi guru-guru MGMP IPS
SMP Kabupaten Banyumas. Workshop ini
menggunakan program QUEST yang telah
teruji dan memiliki kelebihan yaitu
menyajikan hasil analisis berdasarkan teori
tes modern (Subali dan Suyata,
2012).Workshop ini menggunakan metode
ceramah, demonstrasi, tanya jawab
(diskusi), dan praktik langsung


menggunakan perangkat komputer. Tempat kegiatan ini direncanakan di laboratorium Komputer SMP Negeri 2 Sokaraja sebagai lokasi Sekteratiat Pusat MGMP IPS SMP Kabupaten Banyumas. Workshop ini direncanakan akan diikuti oleh 21 orang guru sebagai wakil dari setiap subrayon yang berjumlah 7 subrayon dengan masing-masing subrayon 3 guru mata pelajaran yaitu Ekonomi, Sejarah, dan Geografi.

Adapun pelaksanaan kegiatan terbagi dalam 3 tahapan yaitu :

\section{Tahap pendidikan dan pelatihan}

Pada tahap ini dilaksanakan proses transfer pengetahuan dari instruktur kepada para peserta (mitra kegiatan) berupa:

a. Materi pengetahuan dasar tentang analisis butir soal.

b. Cara mengoperasikan program QUEST

c. Praktik menggunakan program QUEST

d. Menganalisis hasil keluaran program QUEST

2. Tahap pemantauan, dilaksanakan di sekolah terhadap hasil pelatihan yang telah dilakukan dalam penerapannya di sekolah.

3. Tahap evaluasi, dilakukan evaluasi mengenai keberhasilan kegiatan sebagai outcome dari pelaksanaan kegiatan ini.Indikator ketercapaian dari keberhasilan kegiatan adalah para guru mampu menganalisis butir soal yang disusunnya.

\section{HASIL DAN PEMBAHASAN}

Guru-guru yang tergabung dalam MGMP IPS SMP Kabupaten Banyumas berjumlah 314 orang. MGMP IPS SMP ini terbagi dalam 7 subrayon.Setiap subrayon terdiri dari kelompok mata pelajaran Ekonomi, Sejarah, dan Geografi.Kelompok guru ini sebagian telah melakukan analisis butir soal, namun masih terkendala pada sarana yang digunakan.Beberapa guru menggunakan perhitungan manual (kalkulator), beberapa guru telah menggunakan program komputer yaitu ANATES. Seperti telah diketahui bahwa ANATES adalah program aplikasi analisis hasil tes/ulangan soal pilihan ganda atau uraian dalam bentuk validitas, reliabilitas, daya pembeda, dan indeks kesukaran (Admin, 2009).Namun perlu diketahui bahwa jenis analisis butir soal yang digunakan dalam ANATES adalah menggunakan pendekatan model klasik.

Aspek yang perlu diperhatikan dalam analisis butir soal secara klasik adalah setiap butir soal ditelaah dari segi tingkat kesukaran butir, daya pembeda butir, dan penyebaran pilihan jawaban (untuk soal bentuk obyektif) atau frekuensi jawaban pada setiap pilihan jawaban.Penyebaran pilihan jawaban dijadikan dasar dalam analisis butir soal. Hal ini dimaksudkan untuk mengetahui berfungsi tidaknya jawaban yang tersedia. Suatu pilihan jawaban (pengecoh) dapat dikatakan berfungsi apabila pengecoh: 1) paling tidak dipilih oleh $5 \%$ peserta tes/siswa, dan 2) lebih banyak dipilih oleh kelompok siswa yang belum paham materi (Dikmenum, 2008).

Selain pendekatan model klasik, terdapat pendekatan lain dalam menganalisis butir soal yaitu pendekatan modern. Dalam pendekatan modern, penelaahan butir soal menggunakan Item Response Theory (IRT) atau teori jawaban butir soal. Teori ini merupakan suatu teori yang menggunakan fungsi matematika untuk menghubungkan antara peluang menjawab benar suatu soal dengan kemampuan siswa. Nama lain IRT adalah Latent Trait Theory (LTT), atau Characteristics Curve Theory (CCT).Asal mula IRT adalah kombinasi suatu versi hukum phi-gamma dengan suatu analisis faktor butir soal (item factor analysis) kemudian bernama Teori Trait Latent (Latent Trait Theory).Teori ini kemudian sekarang secara umum dikenal menjadi 
teori jawaban butir soal (Item Response Theory) (McDonald, 1999).

Ada empat macam model 1RT (Hambleton (1993) dan Hambleton dan Swaminathan (1985) dalam Dikmenum (2008):

1. Model satu parameter (Model Rasch), yaitu untuk menganalisis data yang hanya menitikberatkan pada parameter tingkat kesukaran soal.

2. Model dua paremeter, yaitu untuk menganalisis data yang hanya menitikberatkan pada parameter tingkat kesukaran dan daya pembeda soal.

3. Model tiga parameter, yaitu untuk menganalisis data yang menitikberatkan pada parameter tingkat kesukaran soal, daya pembeda soal, dan menebak (guessing).

Aspek yang perlu diperhatikan dalam analisis butir soal secara klasik adalah setiap butir soal ditelaah dari segi tingkat kesukaran butir, daya pembeda butir, dan penyebaran pilihan jawaban (untuk soal bentuk obyektif) atau frekuensi jawaban pada setiap pilihan jawaban.Penyebaran pilihan jawaban dijadikan dasar dalam analisis butir soal. Hal ini dimaksudkan untuk mengetahui berfungsi tidaknya jawaban yang tersedia. Suatu pilihan jawaban (pengecoh) dapat dikatakan berfungsi apabila pengecoh: 1) paling tidak dipilih oleh $5 \%$ peserta tes/siswa, dan 2) lebih banyak dipilih oleh kelompok siswa yang belum paham materi (Dikmenum, 2008).

Selain pendekatan model klasik, terdapat pendekatan lain dalam menganalisis butir soal yaitu pendekatan modern. Dalam pendekatan modern, penelaahan butir soal menggunakan Item Response Theory (IRT) atau teori jawaban butir soal. Teori ini merupakan suatu teori yang menggunakan fungsi matematika untuk menghubungkan antara peluang menjawab benar suatu soal dengan kemampuan siswa. Nama lain IRT adalah Latent Trait Theory (LTT), atau Characteristics Curve Theory (CCT).Asal mula IRT adalah kombinasi suatu versi hukum phi-gamma dengan suatu analisis faktor butir soal (item factor analysis) kemudian bernama Teori Trait Latent (Latent Trait Theory).Teori ini kemudian sekarang secara umum dikenal menjadi teori jawaban butir soal (Item Response Theory) (McDonald, 1999).

Ada empat macam model 1RT (Hambleton (1993) dan Hambleton dan Swaminathan (1985) dalam Dikmenum (2008):

1. Model satu parameter (Model Rasch), yaitu untuk menganalisis data yang hanya menitikberatkan pada parameter tingkat kesukaran soal.

2. Model dua paremeter, yaitu untuk menganalisis data yang hanya menitikberatkan pada parameter tingkat kesukaran dan daya pembeda soal.

3. Model tiga parameter, yaitu untuk menganalisis data yang menitikberatkan pada parameter tingkat kesukaran soal, daya pembeda soal, dan menebak (guessing).

Sesuai dengan rancangan kegiatan yang direncanakan, tahapan pelaksanaan kegiatan pengabdian pada masyarakat ini dilaksanakan dalam 3 tahap yaitu pendidikan dan pelatihan, pemantauan, dan evaluasi. Kegiatan diikuti oleh 40 guru IPS SMP yang tergabung dalam MGMP IPS SMP Kabupaten Banyumas. Keempatpuluh guru ini berasal dari 25 sekolah.Secara keseluruhan kegiatan ini dilaksanakan dalam 4 kali pertemuan setiap hari Kamis yaitu tanggal 9, 16, 23 Februari 2017 dan 2 Maret 2017. Rincian kegiatan pada masing-masing pertemuan adalah sebagai berikut:

a. Tanggal 9 Februari 2017. 
Kegiatan pada hari Kamis tanggal 9 Februari 2017 berupa pendidikan dan pelatihan dengan penyampaian materi tentang pengetahuan dasar analisis butir soal, cara mengoperasikan program QUEST sekaligus praktik menggunakan program QUEST, dan menganalisis hasil keluaran program QUEST. Kegiatan ini dilaksanakan di SMP Negeri 2 Purwokerto sebagai pusat kegiatan MGMP IPS SMP Kabupaten Banyumas. Sebelum penyampaian materi, dilakukan survei terhadap kegiatan asesmen kualitas soal tes yang dilakukan oleh guru. Hasil survei diperoleh informasi bahwa sebelum kegiatan ini, selama ini guru masih menggunakan analisis butir soal dengan pendekatan klasik, sehingga belum pernah menggunakan program QUEST. Dengan demikian dapat dikatakan bahwa pengetahuan dan kemampuan mengoperasikan program QUEST masih 0\%.

b. Tanggal 16 Februari 2017: kerja mandiri menyusun soal tes.

c. Tanggal 23 Februari 2017: melakukan uji coba soal tes yang disusun kepada siswa, kemudian dilakukan asesmen kualitas soal yang disusunnya.

Selama kurun waktu 2 minggu ini dilakukan pemantauan terhadap kerja para guru di sekolah masing-masing. Pemantauan dilakukan dengan cara menjalin komunikasi lewat melalui teknologi telpon (SMS, WA, telpon) ataupun internet melalui surat elektronik (email).

d. Tanggal 2 Maret 2017: tahap evaluasi

Kegiatan evaluasi dilaksanakan di SMP Negeri 2 Purwokerto. Sebelum dilakukan evaluasi, terlebih dahulu dilaksanakan diskusi dan paparan hasil kerja guru dalam melakukan asesmen kualitas soal tes yang telah disusun dan diujicobakan ke siswa.

Pada evaluasi ini dilakukan evaluasi mengenai keberhasilan kegiatan sebagai outcome dari pelaksanaan kegiatan ini.Indikator ketercapaian dari keberhasilan kegiatan adalah para guru mampu melakukan asesmen butir soal yang disusunnya. Hasil yang dicapai adalah $100 \%$ dari peserta sudah bisa mengoperasikan dan menjalankan program QUEST sebagai alat bantu melakukan asesmen kualitas soal tes. Hal ini berarti terjadi peningkatan kemampuan sebesar $100 \%$ dari sebelum dilaksanakannya kegiatan ini. Meskipun berasal dari berbagai latar belakang keilmuan, para guru sangat antusias dan bersemangat dalam mengikuti pelatihan ini meskipun sedikit mengalami kendala dalam menyusun instruksi yang dipersyaratkan dalam program QUEST. Kesulitan yang dialami oleh beberapa guru $(25 \%)$ terkait dengan penggunaan program QUEST ini adalah dalam membaca dan menganalisis hasil keluaran program QUEST. Hal ini disebabkan oleh guru baru mengenal program QUEST ini sebagai alat bantu asesmen soal tes yang menggunakan metode modern yaitu metode IRT (Item Respons Theory) atau Teori Respon Butir.

\section{SIMPULAN}

Kegiatan pengabdian pada masyarakat dalam bentuk pelatihan penggunaan program QUEST untuk asesmen soal tes berupa menganalisis butir soal tes dapat meningkatkan profesionalisme guru yang dibuktikan dengan meningkatnya kemampuan guru dalam melakukan asesmen kualitas soal tes dan bertambahnya wawasan dalam pemanfaatan perkembangan teknologi komputer. Dengan demikian diharapkan guru dapat menerapkan hasil yang diperoleh dari pelatihan ini dalam 
Hindayati Mustafidah, Harjono, Agung Purwo Wicaksono

keseharian menjalankan profesi sebagai pendidik yang profesional.

\section{DAFTAR PUSTAKA}

Admin, (2009), Taksonomi Bloom : Mengembangkan Strategi Berpikir Berbasis TIK, http://gurupembaharu.com/pembelaj aran_/perencanaan_/taksonomibloom-mengembangkan-strategiberpikir-berbasis-tik/ diakses tanggal 26 Desember 2009.

Bennyarsih, C., (2006), Korelasi Antara Pembelajaran Remidial dengan Pencapaian Tujuan Pembelajaan Mata Pelajaran PKnPS Pokok Bahasan Perjuangan Melawan Penjajah dan Pergerakan Nasioal pada Siswa Kelas V SD Negeri Segugus Pamuji UPK Karanglewas Semester II Tahun Pelajaran 2005/2006. Skripsi, FKIP UMP. Purwokerto.

Dikmenum, (2008), Panduan Analisis Butir Soal.www.dikmenum.go.id/ dataapp/kurikulum/ 5.\%20perangkat\%20penilaian\%20ktsp $\% 20$ sma/6.\%20analisis\%

20butir\%20soal/panduan\%20analisi s\%20butir\%20soal.doc, diakses 20 Nopember 2008.

Dwiningsih, Y., (2006), Analisis Sistem Evaluasi Kurikulum 2004 Beberapa SMA Swasta pada Mata Pelajaran Biologi Kelas X Tahun Pelajaran 2004/2005 di Kabupaten Banyumas, Skripsi, FKIP Universitas Muhammadiyah Purwokerto, Purwokerto.

Hani, D.F., (2006), Analisis Butir Soal Akhir Semester Genap Kelas X Bidang Studi Biologi Kurikulum 2004 Tahun Pelajaran 2005/2006 di SMA Negeri Kabupaten Banyumas.Skripsi. FKIP Universitas
Muhammadiyah

Purwokerto, Purwokerto.

McDonald, R.P., (1999), Test Theory: A Unified Treatment, Larvrence Erbaum Associates, Publishers, New Jersey.

Mustafidah, H. dan Pinandita, T., (2011), Pelatihan Pemanfaatan Komputer sebagai Alat Bantu Menganalisis Butir Soal Tes, Laporan Pengabdian pada Masyarakat, Lembaga Penelitian dan Pengabdian pada Masyarakat Universitas Muhammadiyah Purwokerto, Purwokerto.

Sari, R.D.P., (2006), Evaluasi Kualitas Soal Ujian Akhir Semester Genap Mata Pelajaran Biologi Kelas X Tahun Pelajaran 2004/2005 di SMA Negeri 3 Purwokerto, SMA Negeri 4 Purwokerto, dan SMA Negeri Sokaraja, Skripsi, FKIP Universitas Muhammadiyah Purwokerto, Purwokerto.

Subali, B. dan Suyata, P., (2012), Pengembangan Item Tes Konvergen dan Divergen: Penyelidikan Validitasnya secara Empirik, Diandra Pustaka Indonesia, Yogyakarta.

Suwarsito dan Sutomo, (2009), Pelatihan Menentukan Kualitas Soal (Validitas dan Reliabilitas) Menggunakan Alat Bantu Komputer bagi Guru-Guru di Kabupaten Banyumas, Laporan Pengabdian pada Masyarakat, Lembaga Penelitian dan Pengabdian pada Masyarakat Universitas Muhammadiyah Purwokerto, Purwokerto.

Uno, H. B. dan Koni, S., (2012), Assessment Pembelajaran, Bumi aksara, Jakarta. 
Widodo, (2010), Analisis Butir Soal Tes, Jurnal Pendidikan Penabur, 14 (9) $58-67$.

Yusuf, A. M., (2015), Asesmen dan Evaluasi Pendidikan: Pilar Penyedia Informasi dan Kegiatan Pengendalian Mutu Pendidikan, Jakarta : Prenada media Group 